\title{
Effect of Dietary Chitin and Chitosan on Cholesterolemia of Rats
}

\author{
J. ŠIMŮNEK, H. BARTOŇOVÁ, \\ Institute of Animal Physiology and Genetics, Czech Academy of Sciences \\ Prague, Czech Republic \\ Received September 2, 2004 \\ Accepted November 10, 2005
}

\begin{abstract}
Šimůnek J., Bartoňová H.: Effect of dietary chitin and chitosan on cholesterolemia of rats. Acta Vet. Brno 2005, 74: 491-499.

Chitin - chitosan is being advertised as a food supplement that effectively lowers blood cholesterol concentration and controls obesity. The lard-fed rat was chosen because this model shares similarities with human hypercholesterolemia. The male rats were divided into six groups (A-F), each with 6 rats, and fed 6 weeks ad libitum diets prepared on base of commercial diet by addition of lard (diets D, E F), cholesterol (diet C), chitin (diets B, C, D) and chitosan (diet F). There were no significant differences in weight gain and feed efficiencies in all groups during experimental period. The histology examination of liver slices revealed the most pronounced periacinal (3.0) and centroacinal (1.3) steatosis in animals of the group $\mathrm{C}$. In the $\mathrm{F}$ group was detected small periacinal steatosis only. The total serum cholesterol level was significantly increased $(\mathrm{P}<0.05)$ in rats fed high fat diets (D, E, F; $\left.2.21 \pm 0.15,2.25 \pm 0.16,2.27 \pm 0.23 \mathrm{mmol}^{-1} \mathrm{l}^{-1}\right)$ and $\mathrm{C}$ group $\left(2.16 \pm 0.56 \mathrm{mmol} \cdot \mathrm{l}^{-1}\right)$ in comparison with control group $\left(1.57 \pm 0.26 \mathrm{mmol}^{-1^{-1}}\right)$ and group B $\left(1.68 \pm 0.09 \mathrm{mmol} \cdot \mathrm{l}^{-1}\right)$. Similarly HLD-cholesterol levels were in groups B, C, D, E and F increased $(1.02 \pm 0.05,0.90 \pm$ $0.18,1.30 \pm 0.18,1.34 \pm 0.11$ and $1.38 \pm 0.24 \mathrm{mmol} \cdot 1^{-1}$, resp.). While the cholesterol content in liver homogenates was significantly higher in animals fed cholesterol-rich diet $\left(8.79 \pm 0.50 \mathrm{mmol} \cdot \mathrm{g}^{-1}\right.$, $P<0.05)$, chitosan addition significantly depressed the cholesterol concentration $(5.76 \pm 0.95$ mmol.g $\left.\mathrm{g}^{-1}, \mathrm{P}<0.05\right)$. Faecal cholesterol excretion was greatest in the rats of $\mathrm{C}$ group $(13.63 \pm 2.93$ mmol. $\left.\mathrm{g}^{-1}, \mathrm{P}<0.05\right)$. Also faeces of the animals fed the lard-enriched diets contained nonsignificantly more cholesterol than animals of control group. This effect seems to be reinforced by chitosan component in diet $\mathrm{F}$. According to our results $5 \%$ chitin and/or chitosan addition have not prevented any increase in liver weight or the level of plasma cholesterol and also have not reduced the liver cholesterol content in rats fed enriched lard diet. In presence of chitosan higher excretion of faecal cholesterol and lipids were found.
\end{abstract}

Chitin/chitosan, dietary hypercholesterolemia, rats

Chitin is the major constituent of arthropods shells such as crabs, shrimps, lobsters and insects. Annual production of chitin was estimated to $10^{10}$ to $10^{11} \mathrm{t}$, which is close to estimated cellulose production. Although it is not derived from plants, it shares the characteristic with dietary fiber of being a polysaccharide that is indigestible by mammalian digestive enzymes. There can be three sources of chitinolytic enzymes in the animal's digestive system: from the animal itself, from the endogenous commensal gut microflora, or from the ingested food (Gooday 1990). Chitin - chitosan is being advertised as a food supplement that effectively lowers blood cholesterol concentration and controls obesity. Both are uncritically recommended for curing many other diseases (A saoka 1996). The mechanism by which chitin and chitosan, deacetylated forms of chitin, exert their action, is still poorly understood. Several studies have shown chitosan to be hypocholesterolemic in animal models (LeHoux and Grondin 1993). Chitosan has been suggested to reduce fat absorption from gastrointestinal tract by binding with anionic carboxyl groups of fatty and bile acids, and it interferes with emulsification of neutral lipids (i.e., cholesterol, other sterols) by binding them with hydrophobic bonds (Ylitalo et al. 2002). Inhibition of cholesterol absorption reduces absorption of dietary cholesterol, but more importantly,

Address for correspondence:

MVDr. J. ŠIMÜNEK, CSc.

Institute of Animal Physiology and Genetics

Czech Academy of Sciences, Vídeňská 1083

14220 Prague 4, Czech Republic
Phone: +420 267090509

Fax:+420 267090500

E-mail: simunek@iapg.cas.cz

http://www.vfu.cz/acta-vet/actavet.htm 
prevents reabsorption of biliary cholesterol, which is instead eliminated in the faeces (Cohen 2004). Orally administered chitosan binds fat in the intestine, blocking absorption, and has been shown to lower blood cholesterol in animals and humans (Omrod et al. 1998). Chitosan acts by forming gels in the intestinal tract which entrap lipids but also other nutrients, including fat soluble vitamins and minerals, thus interfering with their absorption (Koide 1998). The hypolipidemic influence of chitosan may also be due to interruption of the enterohepatic bile acid circulation (Razdan and Petterss on 1996) and the reduction in duodenal bile acid concentration (Razdan et al. 1997). Recently, chitosan has shown promise as a carrier in colon targeting, results suggesting that degradation by colonic bacterial enzymes might be one of the important properties of chitosan for its successful use in drugs colon targeting (Tozaki et al. 1997).

In the proposed study, the effects of chitin and chitosan additives on cholesterolemia of rat fed diets with elevated fat contents were investigated. Since the effect of chitosan on decrease of serum cholesterol level in rats has been reported previously, the present study was carried out to compare the effect of chitin, which up to now has not been closely described. The purpose of the present study was to analyze the effect of chitin and chitosan addition on lipid metabolism of rats fed high lipids and cholesterol diets. The lard-fed rat was chosen because this model shares similarities with human hypercholesterolemia.

\section{Materials and Methods}

Animals and diets

Young male Wistar rats were used in the study (VELAZ s.r.o., Koleč, CZ) and weighed approximately 175-192 g. They were housed individually in plastic cages at $24^{\circ} \mathrm{C}$ with 12 -h light $(07.00-19.00 \mathrm{~h})$ and dark cycle. All animals were allowed free access to a diet and water throughout the study period, with the exception of the night prior to blood collections for which the animals were fasted. To accustom the rats to the experimental conditions, they were initially fed the special commercial complete diet ST-1 for laboratory rats prepared by Kocanda Mill Co. (Czech Republic). The composition of the diet was as follows (per kg): nitrogenous components $240.0 \mathrm{~g}$, fiber $37.2 \mathrm{~g}$, fat $34.7 \mathrm{~g}$, ash $65.1 \mathrm{~g}$, calcium $13.2 \mathrm{~g}$, phosphorus $8.7 \mathrm{~g}$, sodium $1.8 \mathrm{~g}$, vitamin A 33200 i.u., D3 cholecalcipherol 2500 i.u., alpha tocopherol $107.9 \mathrm{mg}$, cuprum sulfate pentahydrate $22.6 \mathrm{mg}$ and sodium selenite $0.34 \mathrm{mg}$, antioxidants (butylhydroxytoluen, etoxyquin and butylhydroxyanizole) and citrex powder. After the 20 days adaptation period the animals were randomly divided into six groups, each with 6 rats, and weekly weighed. The compositions of the six used diets are shown in Table 1. All diets were prepared on base of ST-1 diet by addition of commercial lard (diets D, E F), cholesterol (diet C), chitin (diets B, C, D) and chitosan (diet F). Dietary components (cholesterol, chitin from crab shells and chitosan from crab shells) were purchased from Sigma Chemical Co. Chitosan degree of deacetylation was at least $85 \%$. Powdered crab shell chitin was deproteinized, demineralized and decolorated by the procedures of No and Mayers (1997). All groups (A-F) were fed 6 weeks ad libitum.

Table 1. Composition of control and experimental diets $(\mathrm{g})$

\begin{tabular}{|c|c|c|c|c|c|}
\hline Diet & Chitin & Cholesterol & Lard & Chitosan & Basic diet \\
\hline A (control) & 0 & 0 & 0 & 0 & 1000 \\
\hline B & 50 & 0 & 0 & 0 & 950 \\
\hline C & 50 & 10 & 0 & 0 & 940 \\
\hline D & 50 & 0 & 80 & 0 & 870 \\
\hline E & 0 & 0 & 80 & 0 & 920 \\
\hline F & 0 & 0 & 80 & 50 & 870 \\
\hline
\end{tabular}

\section{Sampling}

Faeces and spilled food were collected during 5 last days at the end of the experiment. After 42 days of experiment, the rats were anaesthetized with carbon dioxide gas, weighed and sacrificed by decapitation. Blood was drawn from caudal cava vein. After coagulation the blood serum was separated by centrifugation and stored at $-75^{\circ} \mathrm{C}$ until assayed. The separate parts of the gastrointestinal tract (GIT) and liver were removed and weighed. Fragments of liver tissue were put in $10 \%$ buffered formaldehyde solution and processed for routine histological examination. The rest of the liver and contents of separate parts of GIT and collected faeces samples were frozen at $-75^{\circ} \mathrm{C}$ for next analyses. Samples of GIT content were collected in test tubes and dry matter was determined immediately. 
Biochemical analyses

Determinations of cholesterol, lipoproteins (LDL, VLDL, DHL), triacylglycerol and bilirubin levels in serum were done in professional hospital laboratory enzymatically. Lipids were extracted from liver tissues and faeces homogenates. Cholesterol and triacylglycerols were determined in extracts enzymatically with commercial kits (BIO-LA-TEST CHOL250 and BIO-LA-TEST Triacylglycerols Liquid 400, resp., Pliva-Lachema a.s., Brno, Czech Republic). The atherogenic index was calculated as the LDL:HDL ratio (Usman and Hosono 2000). Faecal fat was determined gravimetrically after Soxhlet extraction with petrol ether on SOXTEC 1043 analysator (Foss Tecator, Denmark). Jejunal and cecal $\mathrm{pH}$ were determined using a combination spear-tip pH microelectrode (model HC 153, Theta ' 90 Co, Czech Republic) at $37{ }^{\circ} \mathrm{C}$. Dry matter of intestinal content was determined gravimetrically after drying at $105^{\circ} \mathrm{C}$ overnight.

\section{Histopathology}

examination was performed in The Analytical Laboratories, Ltd., Plzeň. The samples were stained by Sudan black (Bancroft and Gamble 2002) and routine Hematoxylin-and-eosin staining. The presence of fat in hepatocytes cytoplasm was estimated. The steatosis was classified as periacinal, centroacinal and zonal with 3 intensity levels (1-3, number 1 signified the lowest intensity).

\section{Statistics}

The means and SEM of 6 rats per group are reported. The significance of differences among values was analyzed by one-way ANOVA (Oda et al. 1991). When the interaction was significant, Student's t-test was performed (Snedecor and Cochran 1967). $P$ values of $<0.05$ were considered significant. All statistical analyses were performed using the General Linear Model Procedure (SAS, 1985).

Ethical considerations

The experimental protocol was performed according to international and national guidelines. The animal experiment was approved by the Ethic Committee of the Czech Academy of Sciences.

\section{Results}

The objective of the present study was to determine the effect of chitin a chitosan on lipid metabolism of conventional rats fed diets with different fat and cholesterol levels. In addition to the control diet $\mathrm{A}$, we prepared the diet $\mathrm{B}$ without addition of fat substances as a reference diet of pure chitin effect. The diet $\mathrm{C}$ was constructed to simulate a high dietary cholesterol intake. The animals of the groups D, E and F were loaded by $8 \%$ of lard in pellets. The expected negative effect on lipid metabolism of this fat diet would be corrected by addition of $5 \%$ chitin (diet D) and 5\% chitosan (diet F). All the diets were well accepted by the rats.

The average values of body weights and average daily gains of rats fed control and experimental diets are presented in Table 2. From the data it follows that there were no significant differences in weight gain and feed efficiencies in all groups during 6 the weeks experimental period, although the highest daily gain was achieved in control group animals. The curves of total weight gain of tested groups in the course of all experimental periods (Fig. 1) show very similar slope and there were found no significant differences of growth rate.

Table 2. Body and liver weights and body/liver ratio and average daily gain of rats fed control (A) and experimental (B, C, D, E, F) diets

\begin{tabular}{|l|c|c|c|c|c|c|}
\hline \multirow{2}{*}{ Variable } & \multicolumn{5}{|c|}{ Group } \\
\cline { 2 - 7 } & $\mathrm{A}$ & $\mathrm{B}$ & $\mathrm{C}$ & $\mathrm{D}$ & $\mathrm{E}$ & $\mathrm{F}$ \\
\hline Average daily gain $(\mathrm{g})$ & $2.74 \pm 0.36$ & $2.55 \pm 0.41$ & $2.51 \pm 0.32$ & $2.48 \pm 0.27$ & $2.55 \pm 0.32$ & $2.52 \pm 0.63$ \\
\hline Final body weight $(\mathrm{g})$ & $351.78 \pm 16.50$ & $345.28 \pm 12.33$ & $354.27 \pm 14.23$ & $350.22 \pm 14.43$ & $360.62 \pm 14.31$ & $349.65 \pm 8.21$ \\
\hline Liver weight $(\mathrm{g})$ & $14.54 \pm 1.22$ & $13.30 \pm 1.53$ & $15.09 \pm 0.81$ & $12.85 \pm 1.52$ & $12.97 \pm 1.31$ & $13.72 \pm 2.13$ \\
\hline $\begin{array}{l}\text { Ratio } \\
\text { Body/liver weight }\end{array}$ & 24.2 & 26.0 & 23.5 & 27.3 & 27.8 & 25.5 \\
\hline
\end{tabular}

The values of liver weights and body/liver weight ratios in all groups are shown in Table 2 . The animals of the group $\mathrm{C}$ treated by cholesterol addition have shown the highest average liver weight and the lowest ratio body/liver. The differences are not statistically significant. 
The enriched sterol diet significantly increased the liver weight. The animals of the group C manifested secondary visible effects from the treatment, including yellowish fragile livers with pronounced lobulated structure. The histology examination of liver slices revealed the most pronounced periacinal and centroacinal steatosis in animals of the group C (Fig. 2). In the group F fed chitosan-enriched diet was detected small periacinal steatosis only. No signs of severe liver fat dystrophy were detected.

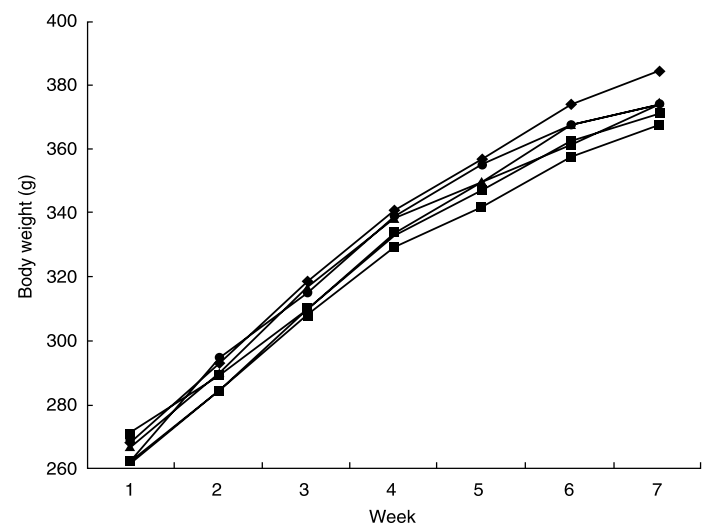

Fig. 1. Mean body weights of rats $\mathrm{A}(\bullet), \mathrm{B}(\boldsymbol{\square}), \mathrm{C}(\boldsymbol{\Delta}), \mathrm{D}(\mathrm{x}), \mathrm{E}(\otimes)$ and $\mathrm{F}(\bullet)$ group.

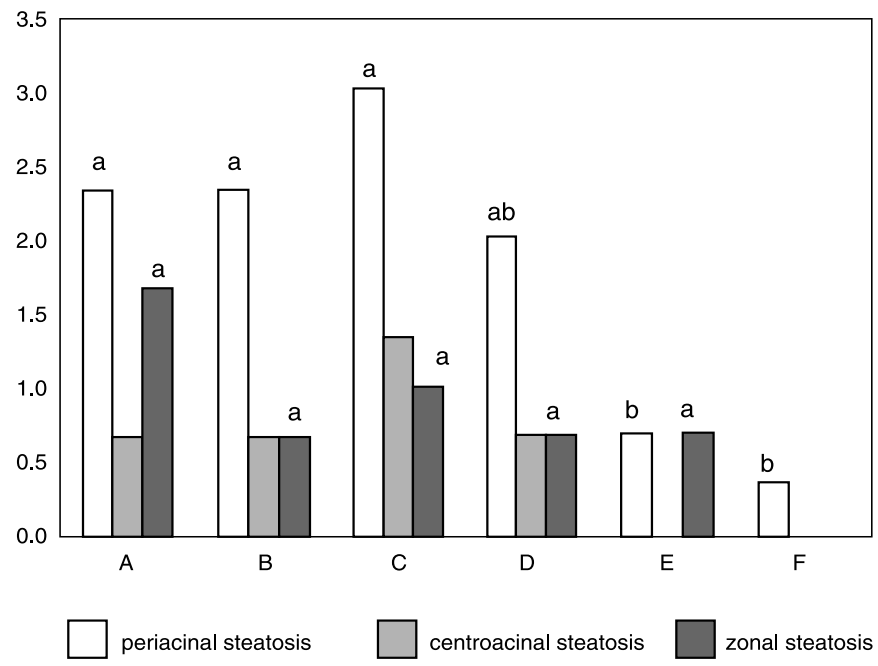

Fig. 2. The intensity of liver steatosis in periacinal, centroacinal and zonal areas ${ }^{a b c}$ Means represented by columns not sharing a common superscript were significantly different $(P<0.05)$

The values of selected lipid parameters of serum are arranged in Table 3. The total serum cholesterol and high-density lipoprotein (HLD) cholesterol levels were significantly increased $(P<0.05)$ in rats fed high fat diets $(\mathrm{D}, \mathrm{E}, \mathrm{F})$ and cholesterol diets $(\mathrm{C})$ in comparison with control group (A) and group fed chitin diet (B). Very-low-density lipoprotein (VLDL) cholesterol and triacylglycerols levels in serum of animals were increased non-significantly. 
Table 3. Cholesterol, $\mathrm{HDL}^{1}$, $\mathrm{VLDL}^{2}$, atherogenic index, triacylglycerols and bilirubin serum levels of rats fed control (A) and experimental (B, C, D, E, F) diets

\begin{tabular}{|l|c|c|c|c|c|c|}
\hline \multirow{2}{*}{ Variable } & \multicolumn{5}{|c|}{ Group } \\
\cline { 2 - 7 } & $\mathrm{A}$ & $\mathrm{B}$ & $\mathrm{C}$ & $\mathrm{D}$ & $\mathrm{E}$ & $\mathrm{F}$ \\
\hline Total cholesterol $\left(\mathrm{mmol} \cdot \mathrm{l}^{-1}\right)$ & $1.57^{\mathrm{a}} \pm 0.26$ & $1.68^{\mathrm{ab}} \pm 0.09$ & $2.16^{\mathrm{ab}} \pm 0.56$ & $2.21^{\mathrm{b}} \pm 0.15$ & $2.25^{\mathrm{b}} \pm 0.16$ & $2.27^{\mathrm{b}} \pm 0.23$ \\
\hline HDL $\left(\mathrm{mmol} \cdot \mathrm{l}^{-1}\right)$ & $0.88^{\mathrm{a}} \pm 0.11$ & $1.02^{\mathrm{c}} \pm 0.05$ & $0.90^{\mathrm{ac}} \pm 0.18$ & $1.30^{\mathrm{b}} \pm 0.18$ & $1.34^{\mathrm{b}} \pm 0.11$ & $1.38^{\mathrm{b}} \pm 0.24$ \\
\hline Cholesterol/HDL & $1.87^{\mathrm{ab}} \pm 0.39$ & $1.64^{\mathrm{a}} \pm 0.05$ & $2.33^{\mathrm{b}} \pm 0.32$ & $1.68^{\mathrm{a}} \pm 0.17$ & $1.63^{\mathrm{a}} \pm 0.08$ & $1.63^{\mathrm{a}} \pm 0.15$ \\
\hline LDL $\left(\mathrm{mmol} \cdot \mathrm{l}^{-1}\right)$ & $0.10 \pm 0.08$ & $0.09 \pm 0.03$ & $0.42^{\mathrm{a}} \pm 0.26$ & $0.07 \pm 0.07$ & $0.02 \pm 0.02$ & $0.01 \pm 0.01$ \\
\hline VLDL $\left(\mathrm{mmol} \cdot \cdot^{-1}\right)$ & $0.86^{\mathrm{a}} \pm 0,20$ & $0.56^{\mathrm{a}} \pm 0.14$ & $0.81^{\mathrm{ab}} \pm 0.25$ & $0.79^{\mathrm{ab}} \pm 0.28$ & $1.02^{\mathrm{b}} \pm 0.29$ & $1.06^{\mathrm{ab}} \pm 0.43$ \\
\hline Atherogenic index & 0 & 0.1 & 0.5 & 0.1 & 0 & 0 \\
\hline Triacylglycerols $\left(\mathrm{mmol} \cdot \mathrm{l}^{-1}\right)$ & $1.81 \pm 0.44$ & $1.24 \pm 0.31$ & $1.62 \pm 0.42$ & $1.87 \pm 0.57$ & $2.25 \pm 0.63$ & $2.34 \pm 0.93$ \\
\hline Bilirubin $\left(\mu \mathrm{mol} \cdot \mathrm{l}^{-1}\right)$ & $6.33 \pm 2.83$ & $6.20 \pm 2.76$ & $3.68 \pm 2.16$ & $6.67 \pm 3.01$ & $6.61 \pm 3.75$ & $5.71 \pm 2.83$ \\
\hline
\end{tabular}

${ }^{1}$ High-density lipoprotein

${ }^{2}$ Very low-density lipoprotein

abc Means within a row not sharing a common superscript were significantly different $(P<0.05)$

On the other hand the significantly highest levels of serum low-density lipoprotein (LDL) cholesterol were found in rats fed the cholesterol-rich diet (C) similarly to the atherogenic index values.

To complete the lipid metabolism pattern the cholesterol and triacylglycerol levels in liver tissue were estimated. While the cholesterol content in liver homogenates was significantly higher in animals fed cholesterol-rich diet (Table 4), chitosan addition significantly depressed the cholesterol concentration. The chitin addition did not show a similar effect (B, D).

Table 4. Liver and faeces levels of cholesterol, triacylglycerols and fat of rats fed control (A) and experimental $(\mathrm{B}, \mathrm{C}, \mathrm{D}, \mathrm{E}, \mathrm{F})$ diets

\begin{tabular}{|c|c|c|c|c|c|c|}
\hline \multirow{2}{*}{ Variable } & \multicolumn{5}{|c|}{ Group } \\
\cline { 2 - 7 } & $\mathrm{A}$ & $\mathrm{B}$ & $\mathrm{C}$ & $\mathrm{D}$ & $\mathrm{E}$ & $\mathrm{F}$ \\
\hline $\begin{array}{c}\text { Liver cholesterol } \\
\left(\mu \mathrm{mol} \cdot \mathrm{g}^{-1}\right)\end{array}$ & $6.44^{\mathrm{a}} \pm 0.78$ & $5.61^{\mathrm{ab}} \pm 1.81$ & $8.79^{\mathrm{c}} \pm 0.50$ & $7.10^{\mathrm{abc}} \pm 1.58$ & $6.00^{\mathrm{ab}} \pm 1.32$ & $5.76^{\mathrm{a}} \pm 0.95$ \\
\hline $\begin{array}{c}\text { Liver triacylglycerols } \\
\left(\mu \mathrm{mol} \cdot \mathrm{g}^{-1}\right)\end{array}$ & $21.75^{\mathrm{ab}} \pm 8.35$ & $16.75^{\mathrm{a}} \pm 3.80$ & $23.75^{\mathrm{ab}} \pm 3.75$ & $24.75^{\mathrm{ab}} \pm 5.90$ & $25.25^{\mathrm{b}} \pm 3.85$ & $25.00^{\mathrm{b}} \pm 3.45$ \\
\hline $\begin{array}{c}\text { Faecal cholesterol } \\
\left(\mu \mathrm{mol} \cdot \mathrm{g}^{-1}\right)\end{array}$ & $6.47^{\mathrm{a}} \pm 1.78$ & $8.55^{\mathrm{a}} \pm 2.01$ & $13.63^{\mathrm{b}} \pm 2.93$ & $8.13^{\mathrm{a}} \pm 1.12$ & $7.08^{\mathrm{a}} \pm 1.47$ & $9.97^{\mathrm{ab}} \pm 3.11$ \\
\hline $\begin{array}{c}\text { Faecal triacylglycerols } \\
\left(\mu \mathrm{mol} \cdot \mathrm{g}^{-1}\right)\end{array}$ & $2.32 \pm 0.78$ & $2.14 \pm 0.58$ & $1.96 \pm 1.03$ & $2.87 \pm 0.81$ & $1.78 \pm 0.77$ & $1.94 \pm 1.11$ \\
\hline $\begin{array}{c}\text { Total lipids in faeces } \\
(\mathrm{g} / 1000 \mathrm{~g})\end{array}$ & $8.70^{\mathrm{a}} \pm 1.26$ & $8.24^{\mathrm{a}} \pm 0.24$ & $26.93^{\mathrm{b}} \pm 1.45$ & $13.14^{\mathrm{c}} \pm 0.45$ & $14.36^{\mathrm{c}} \pm 1.00$ & $16.90^{\mathrm{c}} \pm 0.70$ \\
\hline
\end{tabular}

${ }^{\text {abc }}$ Means within a row not sharing a common superscript were significantly different $(P<0.05)$

As shown in Table 4, faecal cholesterol excretion was greatest in the rats fed cholesterolenriched diet $(\mathrm{C} ; P<0.05)$. Also faeces of animals fed the lard-enriched diets $(\mathrm{D}, \mathrm{E}$ and $\mathrm{F}$ groups) contained more cholesterol than animals of control group. This effect was pronounced particularly in rats receiving chitosan in $\operatorname{diet}$ (group F). Conspicuous differences we found in total fat levels in faeces. The highest total fat excretion was detected in group C. Lower but also significant increase of fat content was found in groups D, E and F. This effect of higher flow of dietary cholesterol and fat into faeces seems to be reinforced by chitosan component in diet F. On the contrary, no significant changes have been detected in faecal triacylglycerol levels. In present experiments $8 \%$ addition of lard into diets raised 
cholesterolemia in experimental rats. Surprisingly, these changes were not followed by appreciable rising of LDL and VLDL cholesterol levels. In rats fed chitin-enriched diets (group B) no significant differences in all followed variables were found with respect to values found in control group (A). Similarly, rats fed high-lipid diets with chitin additive (D) showed no significant differences in comparison with control lard-diet animals (E). Rats fed on diet containing chitin had equivalent liver steatosis, reduced levels of liver triacylglycerols and cholesterol, similar levels of serum and faecal cholesterol and higher excretion of triacylglycerols in faeces. According to our results, $5 \%$ chitin addition to both low- and high-lard diets does not influence cholesterolemia in the rat. Our results suggest that rats fed a diet enriched with $8 \%$ of lard and with added $5 \%$ of chitin maintained an equilibrium between cholesterol intake and de novo cholesterol synthesis comparable to that found in rats fed a normal diet.

Contrary to the chitin effects, addition of 2 to $5 \%$ chitosan to high cholesterol diet in adult rats resulted in a significant reduction, by 20 to $30 \%$, of plasma cholesterol. The concentration of liver cholesterol and triacylglycerols also decreased significantly. The $7.5 \%$ chitosan formula maintained adequate cholesterol homeostasis in rats, despite greatly increased intake of cholesterol. Chitosan almost completely prevented the rise of serum cholesterol in rats at the 5\% dietary level. From data obtained in the study the rats fed the chitosan-fortified diet (F) showed higher concentration of faecal cholesterol, triacylglycerols and total lipids. At the concentration used, chitosan has not prevented any increase in liver weight or the level of plasma cholesterol and also has not reduced the liver cholesterol content when rats were fed the highly enriched lard diet.

According to our results 5\% chitin and/or chitosan addition have not prevented any increase in liver weight or the level of plasma cholesterol and also have not reduced the liver cholesterol content in rats fed enriched lard diet. In presence of chitosan higher excretion of faecal cholesterol and lipids were found.

\section{Discussion}

The animals treated by cholesterol addition have shown in our experiments the highest average liver weight and the lowest ratio body/liver. The results are in compliance with data obtained by LeHoux and Grondin (1993) in their experiments probably due to liver dystrophy. Liver weight was significantly increased by the enriched sterol diet. In rats fed the cholesterol-rich diet (C) we found significantly highest levels of serum low-density lipoprotein (LDL). Lower plasma total cholesterol, LDL-lipoprotein and VLDL-lipoprotein were observed by Yao and Chiang 2002 in rats fed a diet containing chitosan. Similarly in ninety female human volunteers (age 34-70 years) chitosan significantly reduced total cholesterol and LDL cholesterol compared to placebo (Bokura and Kobayashi 2003). Cholesterol homeostasis is achieved when the body balances the rates of synthesis and dietary intake with rates of elimination. Excessive cholesterol may be released from cells and travelled in the blood as a HDL, which is removed by the liver. Indeed, a high proportion of cholesterol in HDL as compared to LDL is beneficial, since it indicates that cholesterol may be travelling away from the blood vessels to the liver. Orm rod et al. (1998) described the significantly lower blood cholesterol levels in the animals (mice) fed for 20 weeks on a diet containing 5\% chitosan and significant inhibition of atherogenesis was also observed. Hypocholesterolemic properties have been attributed to chitosan, especially in rats fed a high cholesterol diet (Sugano et al. 1988) while chitosan at 5\% of the diet lowered the serum cholesterol in rats fed a normal cholesterol diet (Fakada et al. 1991). The hypolipidemic effect of chitosan may be also attributed to the reduction in duodenal bile acid concentration (Razdan et al. 1997). This interruption in enterohepatic bile acid circulation would lead to reduced lipid absorption and increased faecal sterol excretion (Razdan and 
Pettersson 1996). Chitosan significantly increased the faecal cholesterol and triacylglycerol content and significantly decreased liver total lipid and cholesterol contents (Chiang et al.2000). Similarly the chitosan intake caused a higher level of fat to be excreted in the faeces of the corn oil-receiving rats than the lard-receiving ones, although the effect was strong with both diet groups (D e u c hi et al. 1995). On the contrary, chitosan supplement in male volunteers with a high fat intake ( $>120 \mathrm{~g}$ /day) for 12 days did not increase faecal fat content and therefore did not block fat absorption (Gades and Stern 2002).

There is little information on chitin effects available. We found no significant influence of chitin additive in the rats fed high-lipid diets in comparison with control lard-diet animals. Our findings are inconsistent with data of Zacour et al. (1992). The authors studied in Wistar rats fed a diet containing beef tallow (7\%) and cholesterol (1\%) the effect of chitin at the level of $5 \%$ in the diet on cholesterol absorption and metabolism.

Dietary chitosan increased faecal excretion of cholesterol (Sug a no et al. 1980). Increased bile acid excretion could reduce cholesterol concentrations because plasma or liver cholesterol would be utilized to maintain the bile acid pool (Gallaher et al. 2000). Leh oux and Grondin (1993) have found no change in liver weight or appearance after treatment with chitosan.

The weight reduction and decrease in serum LDL cholesterol are important for lowering the risk of cardiovascular attack. Microcrystalline chitosan was found in obese woman to decrease serum LDL cholesterol with no body weight reduction (Wuolijoki et al. 1999).

The hypocholesterolemic effect of chitosan is mediated by beneficial increasing the excretion of total steroid in faeces. The fraction also induces a triacylglycerol-lowering activity in the liver by decreasing hepatic lipogenesis (Tanaka et al. 2001). Chitosan is not specifically hydrolyzed by digestive enzymes, but limited digestion of chitosan due to bacterial flora and to the unspecific enzymes might occur (Ylitalo et al. 2002). This is a possible explanation for the low hypocholesterolemic effect of chitosan found in our experiments. Since the rat caecum and colon have been shown to have much the same microbial contents as the human colon in terms of predominant bacterial species and their levels, and rats are the most readily available and commonly used laboratory animal species, rat cecal and colonic contents or enzymes would by reliable for use as an in vitro degradation system to mimic the microbial environment in the human colon (Zhang and Neau 2002). On the other hand, some chitinases are secreted by gastric mucosa of rat, in many species, however, the intestinal bacterial flora, especially in caeca, is probably the principal source of b-N-acetylglucosaminidase activity (Jeuniaux 1993). The rat bacterial enzymes had the ability to degrade chitosan with extracellular enzymes exhibiting a more profound effect than did cell-associated enzymes (Zhang and Neau 2002). This may be one of the possible explanation of poor chitin and chitosan hypocholesterolemic effects found in our experiments.

\section{Účinek přídavku chitinu a chitosanu v dietě na cholesterolemii potkanů}

Chitin a chitosan jsou stále častěji propagovány jako dietní doplňky určené k účinnému snižování hladiny krevního cholesterolu a snižování obezity. Jako model jsme zvolili potkany krmené dietou s vysokým obsahem sádla. Samci byli rozděleni do 6 skupin (A-F) po 6 zvířatech a krmeni 6 týdnů ad libitum krmivem připraveným na základě komerční kompletní krmné směsi s př́ídavkem $8 \%$ sádla (diety D, E F), $1 \%$ cholesterolu (dieta C), $5 \%$ chitinu (diety B, C, D) a $5 \%$ chitosanu (dieta F). Během pokusu jsme nezaznamenali statisticky významné rozdíly ve hmotnostních přírůstcích a krmné účinnosti mezi jednotlivými skupinami. Histologickým vyšetřením řezů z jaterních excizí jsme nalezli výraznou periacinální $(3,0)$ a centroacinální $(1,3)$ steatózu u zvírat skupiny C. Jaterní řezy zvířat skupiny $\mathrm{F}$ vykazovaly pouze nepatrnou periacinální steatózu. Hladiny celkového 
cholesterolu v krevním séru byly výzmaně zvýšeny $(\mathrm{P}<0,05)$ u potkanů krmených dietou obohacenou tukem (D, E, F; 2,21 $\pm 0,15 ; 2,25 \pm 0,16$ a $2,27 \pm 0,23 \mathrm{mmol} \cdot \mathrm{l}^{-1}$ ) a skupiny C $\left(2,16 \pm 0,56 \mathrm{mmol} \cdot \mathrm{l}^{-1}\right)$ ve srovnání s kontrolní skupinou $\left(1,57 \pm 0,26 \mathrm{mmol} \cdot \mathrm{l}^{-1}\right)$ a skupinou B $\left(1,68 \pm 0,09 \mathrm{mmol} \cdot \mathrm{l}^{-1}\right)$. Obdobně hladiny HLD cholesterolu byly zvýšeny u skupin B, C, $\mathrm{D}, \mathrm{E}$ a F $\left(1,02 \pm 0,05 ; 0,90 \pm 0,18 ; 1,30 \pm 0,18 ; 1,34 \pm 0,11\right.$ a $1,38 \pm 0,24 \mathrm{mmol} \cdot \mathrm{l}^{-1}$, resp. $)$. Zatímco obsah cholesterolu v jaterních homogenátech byl statisticky významně vyšší $(\mathrm{P}<$ $0,05)$ u zvířat krmených dietou s přídavkem cholesterolu $\left(8,79 \pm 0,50 \mathrm{mmol} \cdot \mathrm{g}^{-1}\right)$, přídavek chitosanu významně snížil koncentraci cholesterolu $\left(5,76 \pm 0,95 \mathrm{mmol} \cdot \mathrm{g}^{-1}, \mathrm{P}<0,05\right)$. Vyšší exkrece cholesterolu byla nalezena ve výkalech potkanů skupiny $\mathrm{C}\left(13,63 \pm 2,93 \mathrm{mmol} \cdot \mathrm{g}^{-1}\right.$, $\mathrm{P}<0,05)$. Rovněž výkaly zvířat krmených dietami s vysokým obsahem sádla obsahovaly více cholesterolu než výkaly zvířat kontrolní skupiny. Tento účinek byl zvýšen přídavkem chitosanu $(\mathrm{F})$. Podle našich výsledků př́davek 5\% chitinu nebo chitosanu nezabránil zvýšení hmotnosti jater, zvýšení hladin cholesterolu v séru ani nesnížil obsah cholesterolu v jaterním parenchymu u potkanů krmených dietou s vysokým obsahem sádla. Přídavek chitosanu do krmiva v koncentraci 5\% zvýšil vylučování cholesterolu a lipidů ve výkalech.

\section{Acknowledgements}

The authors thank The Grant Agency of Czech Republic for supporting this work (grant No. 525/00/0984).

\section{References}

ASAOKA K 1996: Chitin-chitosan: The choice food supplement for over 10000 physicians in Japan. Vantage Press, Inc., New York, USA

BANCROFT JD, GAMBLE M: Theory and practice of histological techniques. Churchill Livingstone, London, New York, 2002

BOKURA H, KOBAYASHI S 2003: Chitosan decreases total cholesterol in women: a randomized, double-blind, placebo-controlled trial. Eur J Clin Nutr 57: 721-725

CHIANG MT, YAO HT, CHEN HC 2000: Effect of dietary chitosans with different viscosity on plasma lipids and lipid peroxidation in rats fed on a diet enriched with cholesterol. Biosci Biotechnol Biochem 64: 965-971

COHEN DE 2004: Cholesterol absorption as a target for lipid-lowering therapy. Formulary 39: 3-7

DEUCHI K, KANAUCHI O, IMASATO Y, KOBAYASHI E 1995: Effect of the viscosity or deacetylation degree of chitosan on fecal fat excreted from rats fed on a high-fat diet. Biosci Biotech Biochem 59: 781-785

FAKADA Y, KIMURA K, AYAK, Y 1991: Effect of chitosan feeding on intestinal bile acid metabolism in rats. Lipids 26: 395-399

GADES MD, STERN JS 2002: Chitosan supplementation does not affect fat absorption in healthy males fed a highfat diet, a pilot study. Int J Obesity 26: 119-122

GALLAHER CM, MUNION J, HESSLINK R, WISE J, GALLAHER D 2000: Cholesterol reduction by glucomannan and chitosan is mediated by changes in cholesterol absorption and bile acid and fat excretion in rats. J Nutr 130: 2753-2759

GOODAY GW 1990: The ecology of chitin degradation. In: MARSHALL, KC (Ed.): Advances in microbial ecology. Plenum Press, New York, pp. 378-430.

JEUNIAUX C 1993: Chitinolytic systems in the digestive tract of vertebrates: a review. In: MUZARELLI RAA (Ed.): Chitin enzymology. Eur Chitin Soc, Ancona, pp. 233-244

KOIDE SS 1998: Chitin-chitosan: properties, benefits and risks. Nutrition Res 6: 1091-1101

LEHOUX JG, GRONDIN F 1993: Some effects of chitosan on liver-function in the rat. Endocrinology 132: 1078-1084

NO HK, MEYERS SP 1997: Preparation of chitin and chitosan. In: MUZARELLI RAA, PETER MG (Eds): Chitin Handbook. European Chitin Society, Torrette, pp. 475-489

ODA H, FUKUI H, HITOMI Y, YOSHIDA A 1991: Alternation of serum lipoprotein metabolism by polychlorinated biphenyls and methionine in rats fed a soybean protein diet. J Nutr 121: 925-933

ORMROD DJ, HOLMES CC, MILLER TE 1998: Dietary chitosan inhibits hypercholesterolaemia and atherogenesis in the apolipoprotein E-deficient mouse model of atherosclerosis. Atherosclerosis 138: 329-334

RAZDAN A, PETTERSSON, D 1996: Hypolipidaemic, gastrointestinal and related responses of broiler chickens to chitosans of different viscosity. Br J Nutr 76: 387-397

RAZDAN A, PETTERSSON D, PETTERSSON J 1997: Broiler chicken body weights, feed intakes, plasma lipid and small-intestinal bile acid concentrations in response to feeding of chitosan and pectin. Br J Nutr 78: 283-291

SAS User's Guide, 1985. Statistics, 5 ed., SAS Institute, Inc., Cary, NC

SNEDECOR GW, COCHRAN,WG 1967: Statistical methods, 6th edn., Iowa State University Press, Ames, IA

SUGANO M, FUJIKAWA T, HIRATSUJI Y, NAKASHIMA K, FUKUDA N, HASEGAWA Y 1980: A novel use of chitosan as a hypocholesterolemic agent in rats. Am J Clin Nutr 33: 787-793 
SUGANO M, WATANABE S, KISHI A, IZUME M, OHTAKAR A 1988: Hypocholesterolemic action of chitosans with different viscosity in rats. Lipids 23: 187-191

TANAKA K, IKEDA I, YOSHIDA H, IMAIZUMI K 2001: Effects of dietary defatted squid on cholesterol metabolism and hepatic lipogenesis in rats. Lipids 36: 461-466

TOZAKI H, KOMOIKE J, TADA C, MARUYAMA T, TERABE A, SUZUKI T, YAMAMOTO A, MURANISHI S 1997: Chitosan capsules for colon-specific drug delivery: improvement of insulin absorption from the rat colon. J Pharm Sci 86: 1016-1021

USMAN, HOSONO, A 2000: Effect of administration of Lactobacillus gasseri on serum lipids and fecal steroids in hypercholesterolemic rats. J Dairy Sci 83: 1705-1711

WUOLIJOKI E, HIRVELA T, YLITALO P 1999: Decrease in serum LDL cholesterol with microcrystalline chitosan. Methods Find Exp Clin Pharmacol 21: 357-361

YAO HT, CHIANG MT 2002: Plasma lipoprotein cholesterol in rats fed a diet enriched in chitosan and cholesterol. J Nutr Sci Vitaminol 48: 379-383

YLITALO R, LEHTINEN S, WUOLIJOKI E, YLITALO P, LEHTIMAKI T 2002: Cholesterol-lowering properties and safety of chitosan. Arzneimittel-Forschung-Drug Res 52: 1-7

ZACOUR AC, SILVA ME, CECON PR, BAMBIRRA EA, VIEIRA EC 1992: Effect of dietary chitin on cholesterol absorption and metabolism in rats. J Nutr Sci Vitaminol 38: 609-613

ZHANG H, NEAU SH 2002: In vitro degradation of chitosan by bacterial enzymes from rat cecal and colonic contents. Biomaterials 23: 2761-2766 
